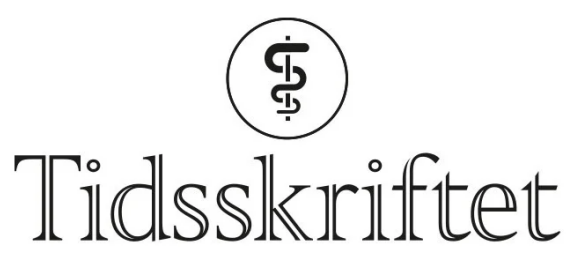

DEN NORSKE LEGEFORENING

\title{
Statistisk udødelighet
}

\author{
MEDISIN OG TALL
}

JAN TERJE KVALØY

jan.t.kvaloy@uis.no

Jan Terje Kvaløy er professor i statistikk ved Institutt for matematikk og fysikk, Universitetet i Stavanger, og seniorrådgiver i medisinsk statistikk ved Stavanger universitetssjukehus. Forfatter har fylt ut ICMJE-skjemaet og oppgir ingen interessekonflikter.

\section{JO RØISLIEN}

Jo Røislien er professor i medisinsk statistikk ved Det helsevitenskapelige fakultet, Universitetet i Stavanger, og en profilert vitenskapsformidler.

Forfatter har fylt ut ICMJE-skjemaet og oppgir ingen interessekonflikter.

\section{Ting tar tid. Det tar tid fra en pasient făr behandling til hen blir frisk, og det tar tid fra noen får en dødelig sykdom til hen dør. Noen tider ønsker man skal være korte, andre lange. Men udødelighet kan bare feilaktig statistisk analyse gi deg.}

Å sammenligne grupper er en av hjørnesteinene i medisinsk forskning, også når vi vil studere tider. Pasientene deles i grupper, og så sammenligner man tiden det tar før en bestemt hendelse skjer i hver av gruppene. Slik kan vi lære noe om hvilke faktorer som forkorter liggetiden på sykehus eller øker sjansen for et langt liv. En særegen utfordring med tid er når selve gruppetilhørigheten er tidsavhengig.

\section{En Oscar forlenger livet?}

I 2001 vant Russell Crowe (f. 1964) en Oscar for sin rolle i Gladiator, og Julia Roberts (f. 1967) for sin rolle i Erin Brockovich. Samme år viste en studie at skuespillere som hadde vunnet en Oscar i gjennomsnitt levde fire år lengre enn sine mindre meritterte kolleger (1 1 ). Å vinne en Oscar så ut til å forlenge livet. Men kan virkelig en gullforgylt statue utsette døden?

I 2006 ble tallene analysert på nytt (모. For mens man har den samme blodtypen hele livet, så er man ikke født Oscar-vinner. Tvert imot vinner man gjerne en Oscar et stykke ut i livet, og en dyktig skuespiller som dør ung har kanskje ikke rukket å vinne en Oscar ennå. Å vinne en Oscar - eller ikke - er ikke en statisk variabel. Ved å retrospektivt dele skuespillerne inn i Oscar-vinnere og ikke, ga man Oscar-vinnerne en statistisk fordel: De kunne ikke dø før etter de hadde vunnet. De var statistisk udødelige. De som døde uten å ha 
fått en Oscar - eller før de hadde vunnet en - ble værende i gruppen med ikke-vinnere. Fenomenet kalles immortal time bias - udødelighetsskjevhet. Når man tok hensyn til dette ble resultatet endret: En Oscar hadde ingen effekt på dødeligheten (ㅁ).

\section{Å ta tiden på alvor}

I medisinsk statistikk dukker udødelighetsskjevhet typisk opp når man deler pasientene inn i grupper basert på noe som skjer underveis i forløpet. Det kan være i forbindelse med analyse av effekt av akkumulerte stråledoser hos kreftpasienter, eller i medikamentstudier der selve designet innfører skjevhet ved at pasienter som får et eksperimentelt medikament allerede har levd lenge nok til å faktisk bli inkludert i studien (3).

Det er vanskelig å spå, særlig om framtiden. Derfor er det kanskje heller ikke så rart at å retrospektivt bestemme gruppetilhørighet på noe som prospektivt endrer seg kan føre til problemer.

\section{Å oppdage udødelighet}

Tiden det tar før noe skjer visualiseres gjerne med Kaplan-Meier-kurver.

Udødelighetsskjevhet kan noen ganger ses direkte i disse kurvene. Figur 1 viser simulerte data som etterligner en studie av effekten av betablokkere hos pasienter med kolorektal kreft (4). Pasientene ble delt i to grupper: De som etter ett år hadde begynt å bruke betablokkere og de øvrige. For å bli med i betablokkergruppen måtte man altså ha overlevd i minst ett år. Denne effekten kan sees ved at betablokkergruppen har en kurve som er flat i starten. Den tilsynelatende signifikante forskjellen mellom gruppene skyldes kun dette året med statistisk udødelighet. En korrekt analyse viser ingen forskjell.

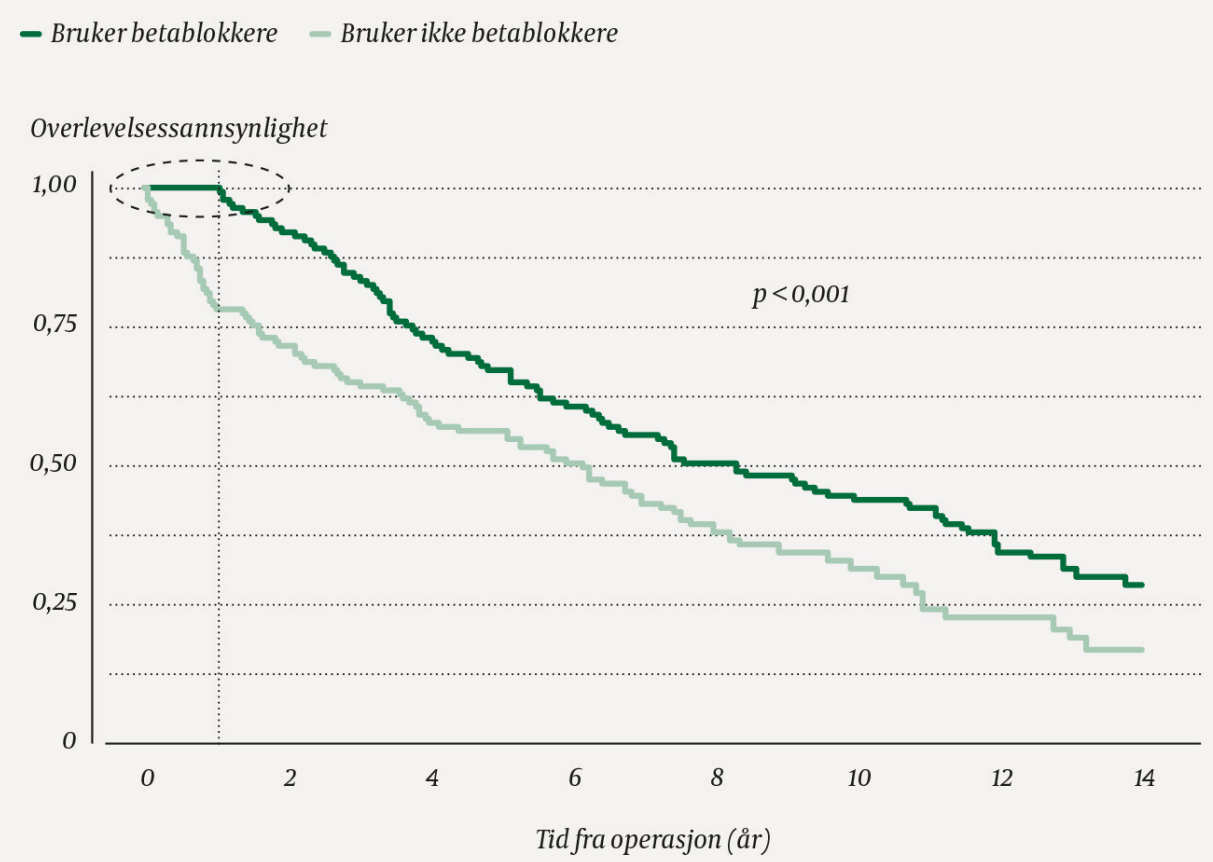

Figur 1 Kaplan-Meier-kurver for simulerte levetider til to grupper kolorektalpasienter, inspirert av (4).

\section{Å unngå udødelighet}


Konsekvensene av å ikke ta høyde for statistisk udødelighet vil være at man innfører en skjevhet i resultatene, og konklusjonene kan bli gale. Heldigvis kan problemet unngås. Det enkleste er å behandle gruppetilhørigheten som det den faktisk er: en tidsavhengig forklaringsvariabel. Dette kan statistikkens verktøyskrin enkelt håndtere.

\section{Lev lenge og vinn en Oscar}

Ting tar tid. Og det som tar lengst tid er å bli gammel og dø. Den amerikanske filmskaperen James Ivory (f. 1928) ble nominert til en Oscar både i 1986, 1993 og 1994, men det var først i 2017, da han i en alder av 89 år ble ropt opp på scenen for endelig å vinne en Oscar, at han som tidenes eldste Oscar-vinner ble flyttet over i gruppen «Oscar-vinner». Det å leve lenge øker sjansen for å vinne en Oscar - men ikke motsatt.

\section{LITTERATUR}

1. Redelmeier DA, Singh SM. Survival in Academy Award-winning actors and actresses. Ann Intern Med 2001; 134: 955-62. [PubMed][CrossRef]

2. Sylvestre MP, Huszti E, Hanley JA. Do OSCAR winners live longer than less successful peers? A reanalysis of the evidence. Ann Intern Med 2006; 145: 361-3, discussion 392. [PubMed][CrossRef]

3. Suissa S. Immortal time bias in pharmaco-epidemiology. Am J Epidemiol 20o8; 167: 492-9. [PubMed][CrossRef]

4. Weberpals J, Jansen L, van Herk-Sukel MPP et al. Immortal time bias in pharmacoepidemiological studies on cancer patient survival: empirical illustration for beta-blocker use in four cancers with different prognosis. Eur J Epidemiol 2017; 32: 1019-31. [PubMed][CrossRef]

Publisert: 7. mai 2021. Tidsskr Nor Legeforen. DOI: 10.4045/tidsskr.21.0123

(C) Tidsskrift for Den norske legeforening 2023. Lastet ned fra tidsskriftet.no 26. april 2023. 